\title{
INTEGRASI PROSES BISNIS PADA PERUSAHAAN GALANGAN KAPAL PT "XYZ" SHIPYARD MENGGUNAKAN OPENERP
}

\author{
Lily Puspa Dewi ${ }^{1}$, Yulius Hari $S^{2}$, dan Uce Indahyanti ${ }^{3}$ \\ ${ }^{1}$ Program Studi Teknik Informatika, Fakultas Teknologi Industri, Universitas Kristen Petra \\ ${ }^{2}$ Teknik Informatika, Universitas Widya Kartika Surabaya \\ ${ }^{3}$ Program Studi Teknik Komputer Politeknik SAKTI Surabaya \\ E-mail: lily@petra.ac.id, yulius.hari.s@gmail.com, indahyantiuce@yahoo.com
}

\begin{abstract}
Abstrak: Pada industri galangan kapal, komponen penyusun sebuah kapal sangat bervariasi dan banyak. Kapal diproduksi berdasarkan pesanan dan menyesuaikan dengan permintaan konsumen. Proses bisnis yang terjadi pada perusahaan galangan kapal dalam proses pembuatan kapal melalui beberapa tahap, mulai dari desain hingga pengiriman kapal jadi ke konsumen. Proses-proses tersebut masih dilakukan secara manual sehingga dapat menimbulkan beberapa kesulitan dan membutuhkan waktu yang lama dalam pengerjaannya. Untuk mengatasi masalah tersebut, dibutuhkan sistem yang mampu mempercepat dan mempermudah operasional proses bisnis pada perusahaan galangan kapal ini. Sistem informasi yang dimaksud adalah Enterprise Resource Planning (ERP). Penelitian ini menilik mengenai implementasi OpenERP di perusahaan PT. XYZ sebagai aplikasi untuk mengintegrasikan proses bisnisnya. Hasil penelitian ini menunjukkan bahwa OpenERP dapat menjawab permasalahan yang dihadapi pada proses bisnis perusahaan galangan kapal ini. Dengan menggunakan sistem ERP ini menawarkan sistem terintegrasi di dalam perusahaan, tetapi keberhasilan sistem ERP tergantung pada strategi implementasi yang diterapkan. Pengguna merasakan manfaat dari sistem ERP ini. Tetapi ada keraguan dari pengguna untuk berpindah sistem, alasan utama keraguan pengguna untuk berpindah sistem adalah tradisi, kultur, waktu dan biaya proses perpindahan sistem.
\end{abstract}

Kata kunci: Galangan kapal, Open ERP, enterprise resource planning.

\begin{abstract}
In the shipyard industry, ships produced by order and adjust to consumer demand. Business processes that occur at the shipyard company in the shipbuilding process through several stages, ranging from design to delivery. Processes are still done manually so it may cause some difficulty and time. For the solution, system capability is needed to accelerate the business process. This research considers the OpenERP implementation at PT. XYZ as an application for integrating business processes. The results of this study indicate that OpenERP can answer the problems faced by the business process shipyard company. By using this ERP system offers company integrated system, but success depends on the ERP system implementation strategies are applied. Users can take benefit from the ERP system. The problems of this migration system are on tradition, culture, time and cost.
\end{abstract}

Keywords: Shipyard, Open ERP, enterprise resource planning

\section{PENDAHULUAN}

Galangan kapal (shipyard) adalah sebuah tempat yang dirancang untuk membuat dan memperbaiki kapal. Pada umumnya, industri galangan kapal mempunyai dua bisnis utama yaitu pembuatan kapal baru (new build) dan jasa reparasi (repair and docking). Sedangkan jenis kapal yang diproduksi bervariasi mulai dari kapal perang, kapal patroli, kapal ferry dan penumpang, kapal cargo, sampai dengan kapal pesiar bahkan jenis kapal lainnya.

Komponen-komponen penyusun kapal sangat banyak dan bervariasi, tetapi pada umumnya hampir sama untuk setiap jenis kapal. Perbedaan yang ada terutama terletak pada spesifikasi komponen dan tambahan peralatan tertentu sesuai fungsi kapal tersebut, misal panjang dan model plat, jenis mesin induk, jenis radar, jenis peralatan navigasi dan komunikasi, cargo handling system, dan lain-lain.

Pada penelitian ini, proses bisnis yang dibahas adalah proses bisnis pembuatan kapal baru yang berfokus pada pemenuhan kebutuhan pasar kapal pratoli cepat 14 meter.

Proses bisnis yang terjadi pada pembuatan kapal tersebut diawali dengan proses bisnis perencanaan yang terdiri dari proses bisnis desain, perencanaan produksi, pembelian material dan inventori. Lebih lanjut, proses bisnis yang dilakukan berikutnya adalah proses bisnis produksi. Setelah proses produksi dan kapal dinyatakan telah selesai, proses bisnis pengiriman/distribusi dilaksanakan. 
Proses-proses tersebut masih dilakukan secara manual sehingga dapat menimbulkan beberapa kesulitan dan membutuhkan waktu yang lama dalam pengerjaannya. Beberapa masalah yang dihadapi pada pelaksanaan secara manual tersebut seperti kesulitan saat melakukan pembelian sesuai dengan kapal yang dipesan, mengatur proses produksi kapal dalam kurun waktu sesuai perjanjian, pengaturan pengiriman kapal jadi dan perhitungan laba rugi pada transaksi jual beli yang terjadi.

Untuk mengatasi masalah tersebut, dibutuhkan sistem yang mampu mempercepat dan mempermudah operasional proses bisnis pada perusahaan galangan kapal ini. Sistem informasi yang dimaksud adalah Enterprise Resource Planning (ERP).

Agar mendapatkan manfaat yang sebesar-besarnya dari sistem Enterprise Resource Planning (ERP), maka proses bisnis pada sebuah industri sebaiknya mengikuti best practice process (proses umum terbaik) yang berlaku. Disini banyak timbul masalah dan tantangan, misalnya bagaimana merubah proses bisnis yang berjalan di perusahaan agar sesuai dengan proses bisnis yang dihendaki oleh sistem atau software ERP atau sebaliknya [1].

Proses penyesuaian itu sering disebut sebagai proses implementasi. Jika dalam kegiatan implementasi diperlukan perubahan proses bisnis yang cukup mendasar, maka perusahaan ini harus melakukan Business Process Reengineering yang dapat memakan waktu berbulan bulan. Investasi ERP sangat mahal dan dapat menimbulkan risiko yang besar, maka sangat diperlukan metodologi pemilihan software ERP. Bahkan dalam beberapa kasus yang ekstrim, evaluasi pilihan ERP menghasilkan rekomendasi untuk tidak membeli atau menunda pembelian ERP, tetapi memperbaiki proses bisnis yang ada terlebih dahulu $[2,3]$.

Tujuan dari penelitian ini mengimplementasikan ERP untuk mendukung fungsi bisnis perusahaan, terutama untuk integrasi data pada proses bisnis pembelian, produksi dan penjualan.

\section{TINJAUAN PUSTAKA}

\section{Enterprise Resource Planning}

Enterprise Resource Planning (ERP) adalah sistem informasi bagi perusahan manufaktur maupun jasa, yang berperan mengintegrasikan dan mengotomasikan proses bisnis. Software ERP mendukung proses bisnis yang efisien dengan mengintegrasikan aktivitas bisnis, termasuk penjualan, pemasaran, produksi, logistik, akuntansi dan sumber daya manusia [4].
Berikut keuntungan penggunaan ERP:

- Integrasi data keuangan sehingga top management bisa melihat dan mengontrol kinerja keuangan perusahaan dengan lebih baik

- Standarisasi Proses Operasi, yang dilakukan melalui implementasi best practice sehingga terjadi peningkatan produktivitas, penurunan inefisiensi dan peningkatan kualitas produk

- Standarisasi Data dan Informasi dilakukan melalui keseragaman pelaporan, terutama untuk perusahaan besar yang biasanya terdiri dari banyak business unit dengan jumlah dan jenis bisnis yg berbeda-beda

Sistem Enterprise Resource Planning (ERP) dirancang berdasarkan proses bisnis yang dianggap best practice yaitu proses umum yang paling banyak dipakai. Misalnya, bagaimana proses umum yang sebenarnya berlaku untuk bagian pembelian (purchasing), pengaturan dan pengelolaan stok barang di gudang dan sebagainya [5].

\section{Open ERP}

OpenERP adalah sebuah perangkat lunak manajemen perusahaan berbasis Open Source. Aplikasi ini mampu melakukan seluruh otomatisasi perusahaan, meliputi sebagian besar kebutuhan dan proses perusahaan yang terintegrasi. Software ini akan membantu perusahaan untuk mengendalikan semua kegiatan secara otomatis. Misalnya kegiatan penjualan akan secara otomatis membuat perintah produksi, input akuntansi diperbarui oleh operasi stok, surat masuk yang dilacak dalam sistem, dan sistem manajemen dokumen terpadu membantu tim Anda untuk berkolaborasi. Sistem ini dapat dimplementasikan secara modular. Perusahaan dapat memulai implementasi dengan salah satu modul yang dikustom berdasarkan kebutuhan perusahaan tersebut, kemudian berkembang sesuai kebutuhan sampai akhirnya menjadi sebuah solusi terintegrasi. Modul yang terdapat dalam aplikasi adalah: akuntansi, HRD, Penjualan, CRM, Pembelian, Manajemen Produksi, Manajemen Proyek, dan Pengelolaan Sumber Daya [6].

OpenERP menawarkan tiga tingkat arsitektur web, kemudahan penggunaan dan fleksibilitas, sehingga user dapat memilih apakah ingin menggunakan browser untuk OpenERP client server atau menggunakan application client (GTK client) yang diinstall di tiap computer. Tiga komponen utama dalam arstitektur OpenERP adalah [5]:

1. Dataserver: PostgreSQL untuk menyimpan database 
2. Aplikasi Server: OpenERP yang menjalankan logic dalam aplikasi OpenERP

3. Web server, aplikasi yang disebut Open Object client-web sehingga dari berbagai macam browser dapat terhubung ke OpenERP. Obyek ini tidak dibutuhkan kalau user menggunakan GTK client.

\section{PROSES BISNIS}

Setelah dinyatakan menang dalam tender, perusahaan akan menerima surat penunjukan sebagai pemenang tender. Dengan diterimanya surat penunjukkan pemenang tender maka proses desain pembuatan dimulai. Proses diawali dengan perancangan kapal yang dikerjakan oleh Bagian Design and Engineering (DE). Desain kapal mengacu pada spesifikasi teknis kapal yang tertuang dalam kontrak. Desain yang sudah jadi akan dilakukan uji model dalam lab hydrodinamika untuk menguji kestabilan kapal dan perkiraan kecepatan maksimum yang bisa dicapai oleh kapal dan perlu disetujui oleh badan klarifikasi yang ditunjuk. Dari gambar desain, dillakukan breakdown menjadi gambar produksi (production drawing) yang lebih detail. Berdasarkan production drawing bisa dihitung kebutuhan material plat dan profil yang meliputi volume, ukuran maupun spesifikasinya. Proses bisnis ini ditampilkan dengan BPMN seperti pada Gambar 1.

Perencanaan Produksi disusun oleh Bagian PPC (Production Planing \& Control) meliputi pembuatan jadwal pembangunan kapal. Berdasarkan jadwal pembangunan kapal, production drawing dan spesifikasi teknis kapal, bagian PPC membuat permintaan pembelian material secara bertahap sesuai dengan urutan pembangunan kapal, dan juga menghitung kebutuhan tenaga kerja (jam orang). Bagian PPC berkoordinasi dengan Bagian Pembelian untuk memperoleh gambaran delivery time (lead time) dari masing-masing material atau mesin yang akan dibeli. Proses bisnis ini ditampilkan pada Gambar 2.

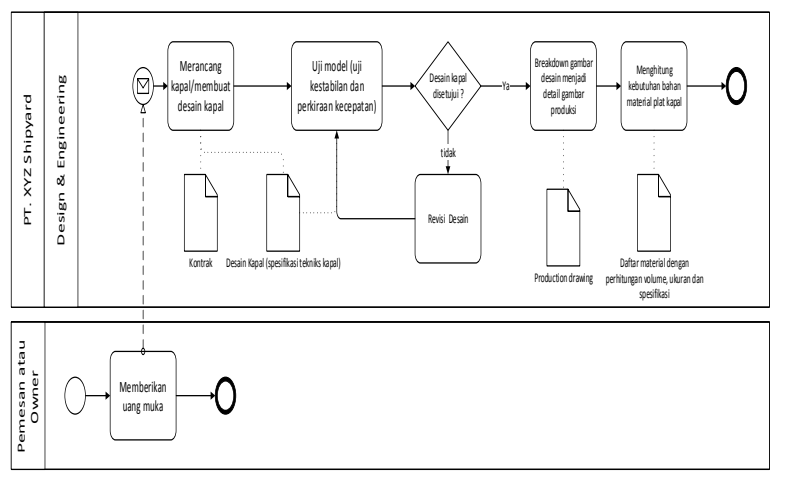

*Pemesan atau Owner bersas ddari instansi pemerinth (Departemen Perthanana, Kepolisan Rl, Departemen Kelautan, dan lain-lain)

Gambar 1. BPMN Proses Desain

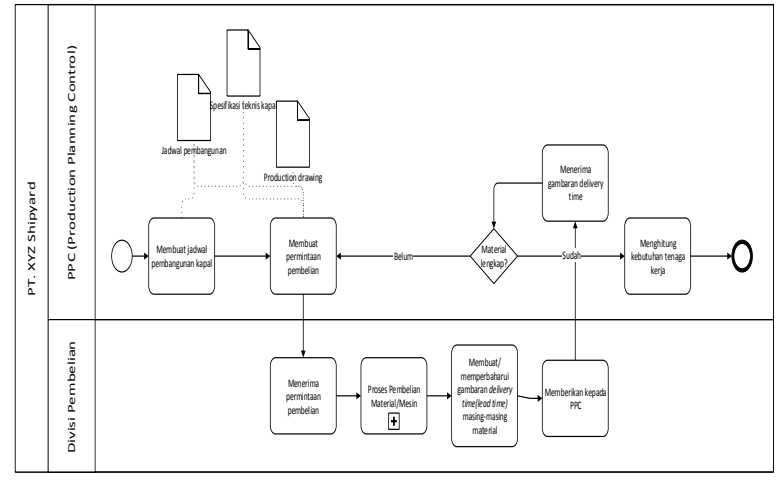

Gambar 2. BPMN Proses Produksi

Berdasarkan permintaan material dari Bagian PPC, Bagian Pembelian mencari penawaran minimal dua supplier dan mengajukan usulan anggaran pembelian material kepada Direktur Keuangan. Pengajuan anggaran dilakukan dua kali dalam seminggu. Direktur Keuangan memeriksa anggaran dan menentukan material yang bisa dibeli dan melalui supplier mana (proses pembelian material). Setelah mendapat persetujuan dari Direktur Keuangan, Bagian Pembelian membuat Purchase Order kepada supplier atau melakukan pembelian secara langsung. PO ini dibuat rangkap tiga, dua salinan PO akan diberikan ke petugas Material Kontrol (MK) dan Bagian Gudang. Pada saat barang dikirim dari supplier, petugas MK mencocokkan dengan PO dan Surat Jalan dari Supplier. Jika sesuai dan lengkap, petugas MK akan mencatat barang yang datang tersebut pada form Bon Penerimaan Barang (BPB). BPB terdiri dari tiga rangkap yaitu untuk Bagian Pembelian, untuk Bagian Gudang dan untuk petugas MK itu sendiri. Sedangkan supplier hanya menerima bukti Surat Jalan yang telah di tanda tangani dan distempel oleh petugas MK dan Bagian Gudang. Bagian Gudang menggunakan BPB untuk mencatat barang masuk. Pada BPB terdapat data lengkap mengenai spesifikasi material termasuk peruntukannya untuk pembuatan kapal jenis apa. Sedangkan untuk barang yang keluar dari gudang dicatat pada Bon Permintaan Material (BPM) dan disebutkan juga untuk proyek pembuatan kapal jenis apa. Dan setiap akhir bulan permintaan material akan direkap. Hasil rekap diserahkan ke Bagian Keuangan (sub bag akuntansi), kemudian Bagian Keuangan membuat Production Cost Report (PCR). Jika ada material yg sudah dikeluarkan tapi ternyata tidak digunakan akan dikembalikan ke gudang dan dicatat pada Bon Retur Gudang (BRG). Setiap akhir bulan dilakukan rekapitulasi pemakaian material untuk masing-masing proyek pembangunan kapal berdasarkan BPM dan BRG yang ada. Hasil rekap diserahkan ke Bagian Akuntasi sebagai dasar untuk pembuatan Laporan Biaya Produksi (LPB) untuk masing masing proyek 
pembangunan kapal. Bagian pembelian akan menggunakan BPB dan Surat Jalan sebagai kelengkapan data untuk pembayaran hutang dan temponya. Bagian Pembelian mengajukan kedua dokumen tersebut ke Bagian Keuangan (sub bag hutang) untuk mencairkan dana tersebut. Proses bisnis ini dapat dilihat pada Gambar 3.

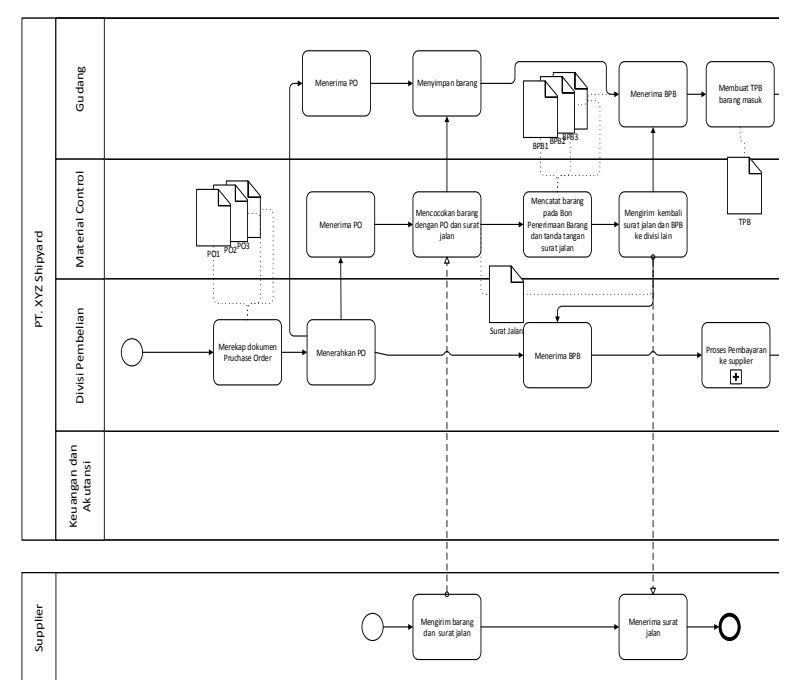

Gambar 3. BPMN Proses Inventory

Proses produksi dimulai dari proses engineering atau desain dilanjutkan proses konstruksi lambung dan pengecatan, kemudian proses pemasangan interior dan akomodasi perlengkapan, terakhir pemasangan mesin, kelistrikan dan perlengkapan navigasi. Bangunan kapal dibagi dua yaitu bangunan bawah air (bagian bawah kapal) dan bangunan atas air (bagian atas air). Bangunan bawah air dikerjakan sepenuhnya di galangan kapal, sedangkan bangunan atas air dapat dikerjakan 75\%-90\% di galangan kapal, proses finishing dapat dilanjutkan setelah kapal dilaunching (diluncurkan ke laut). Biaya produksi meliputi: biaya material, biaya tenaga kerja produksi (jasa pekerjaan dan engineering), biaya pengeluaran umum, dan biaya profit dan resiko.

\section{PENYUSUNAN RENCANA DAN STRATEGI PENGUJIAN}

Pengujian ditujukan untuk melihat proses kinerja sistem dan juga hasil dari sistem ERP tersebut. Selain itu juga bertujuan untuk melihat kekurangan yang terjadi. Pengujian sistem dilakukan dalam berbagai skenario yang mungkin terjadi di PT XYZ.

Selain itu juga dilakukan analisis mengenai fungsi sistem ERP dari sisi pengguna. Metode yang dilakukan adalah dengan memberikan pertanyaan tentang sistem ERP yang telah diimplementasi. Pertanyaan dapat terlihat pada Tabel 1.
Tabel 1. Pertanyaan untuk Pengujian Sistem

\begin{tabular}{cl}
\hline No & \multicolumn{1}{c}{ Pertanyaan } \\
\hline $1 \quad$ Apakah menurut anda sistem baru (sistem ERP) \\
membantu proses bisnis anda? \\
2 Apakah menurut anda sistem baru menghambat \\
kinerja dan keberlangsungan proses bisnis? \\
3 Apakah menurut anda sistem baru bersifat user \\
friendly dan mudah dipahami? \\
4 Apakah menurut anda sistem baru yang telah \\
diterapkan beberapa hari ini lebih baik dari sistem \\
lama? \\
5 Apakah anda setuju jika sistem baru ini diterapkan \\
dalam waktu dekat sebagai sistem yang nantinya \\
membantu anda dalam menjalani proses bisnis? \\
6 Apakah anda setuju jika tetap menggunakan sistem \\
lama daripada menggunakan sistem baru sebagai \\
pendukung proses bisnis anda? \\
7 Jika anda tidak setuju untuk menggunakan sistem \\
ERP dalam waktu dekat ini, apakah di masa \\
mendatang anda setuju untuk menerapkannya?
\end{tabular}

\section{PENGUJIAN SISTEM}

Inisialisasi proses bisnis pada OpenERP dilakukan dengan memasukkan produk berupa jenis material yang dipakai dalam pembuatan kapal (Modul Product) seperti terlihat pada Gambar 4.

Pada material tersebut kita temukan banyak yang berwarna merah karena memiliki stok dibawah 0 nol. Oleh karena itu untuk melakukan penambahan material dilakukan proses pembelian dengan pembuatan Purchase order (PO). Dimana dapat kita temukan di modul Purchase Management seperti terlihat pada Gambar 5.

Proses dilanjutkan dengan penerimaan barang sesuai dengan PO yang telah dibuat seperti terlihat pada Gambar 6.

Pada proses penerimanan barang dapat dilakukan perubahan jumlah (tidak sesuai PO) sesuai dengan jumlah nyata barang yang terima (make picking). Penerimaan barang ini langsung berpengaruh terhadap jumlah stok barang tersebut (modul Stock Management).

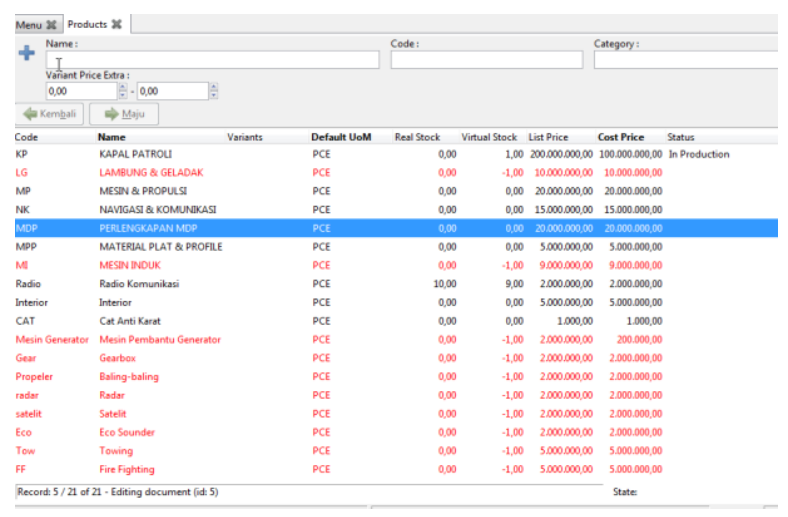

Gambar 4. Tampilan BOM di OpenERP 


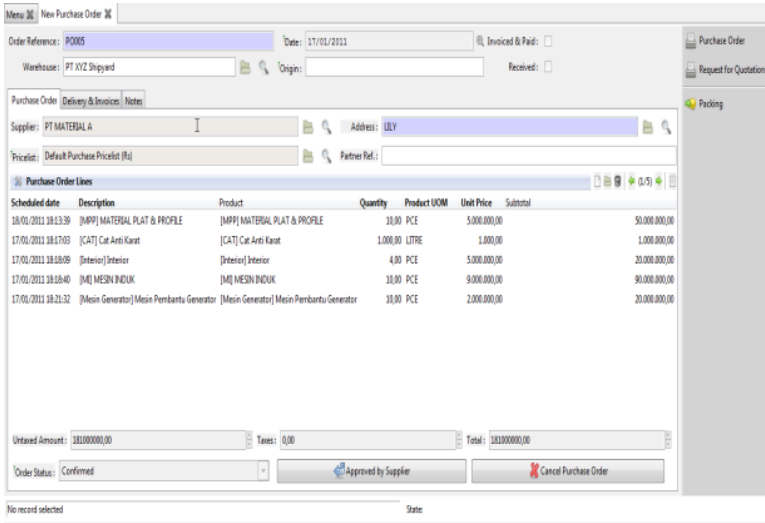

Gambar 5. Tampilan Purchase Order yang dipesan

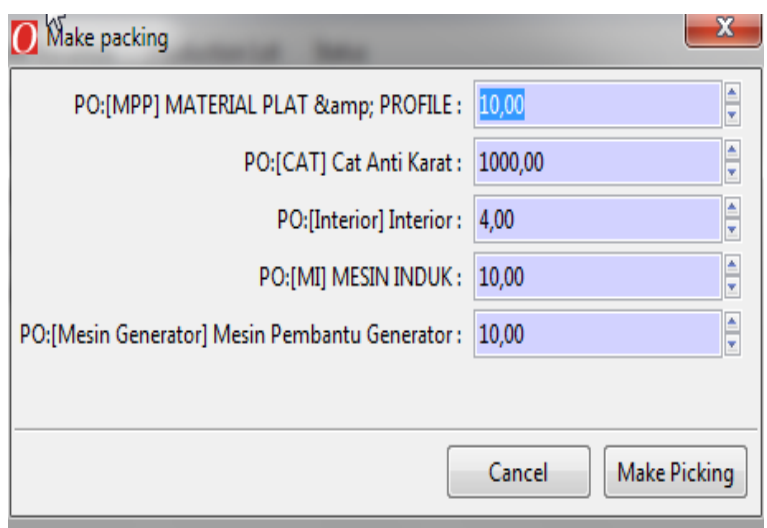

Gambar 6. Tampilan Proses Penerimaan Barang

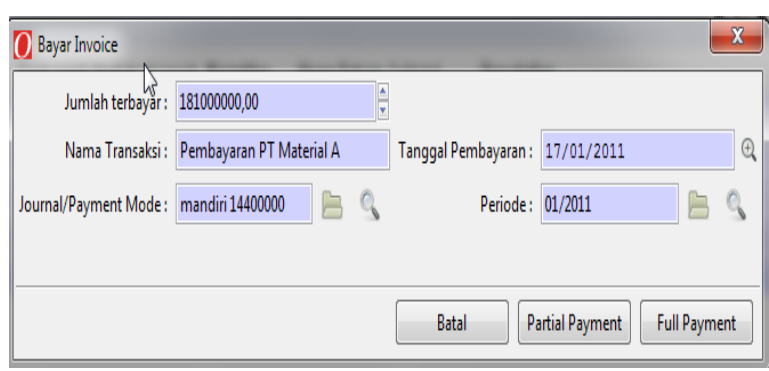

Gambar 7. Tampilan Proses Pembayaran

\begin{tabular}{llrrr} 
Kode & Akun & Debit & Kredit & Saldo \\
\hline 0 & PT XYZ Shipyard & 362000400,00 & 362000400,00 & 0,00 \\
\hline 1 & Balance Sheet & 181000200,00 & 362000400,00 & $-181000200,00$ \\
\hline 10 & Fxed Assels & 0,00 & 0,00 & 0,00 \\
\hline 100000 & Frxed Asset Account & 0,00 & 0,00 & 0,00 \\
\hline 11 & Net Current Assets & 181000200,00 & 362200440,00 & $-181000200,00$ \\
\hline 110 & Current Assets & 0,00 & 181000200,00 & $-181000200,00$
\end{tabular}

Gambar 8. Tampilan Necara Saldo

Modul Financial Management dipakai untuk melakukan pembayaran terhadap supplier berdasarkan PO yang telah dibuat sebelumnya seperti pada Gambar 6. Setelah itu akan tampil laporan yang menampilkan status Neraca kita seperti pada Gambar 8.
Pada saat konsumen memesan sebuah kapal, proses produksi pembuatan kapal dimulai pada modul Manufacturing. Proses ini dimulai dengan membuat BOM dan menyimpannya ke dalam database seperti terlihat pada Gamkbar 9.

Proses secara otomatis mengakibatkan perubahan stock barang. Lebih lanjut, proses pembuatan penawaran kepada konsumen yang memesan dilakukan pada modul Sales and Management.

Proses pembayaran berdasarkan penawaran tertentu dilakukan pada modul Financial Management seperti terlihat pada Gambar 11.

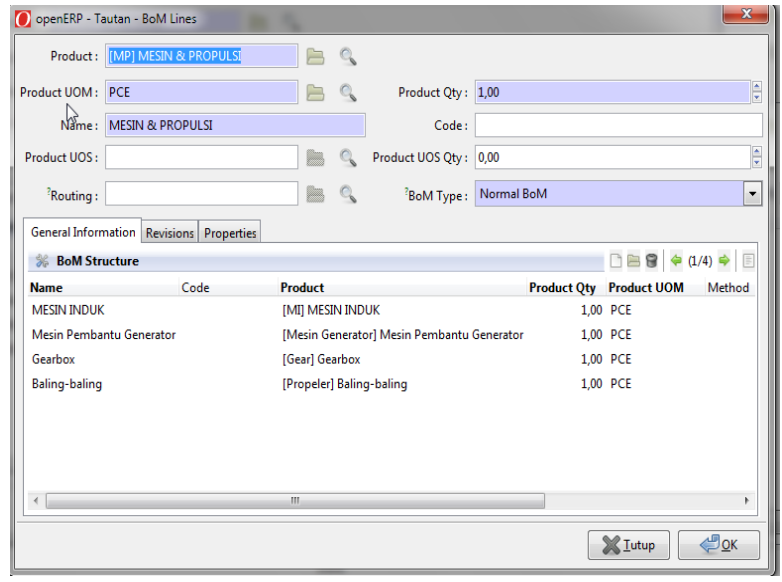

Gambar 9. Tampilan Pengisian BOM

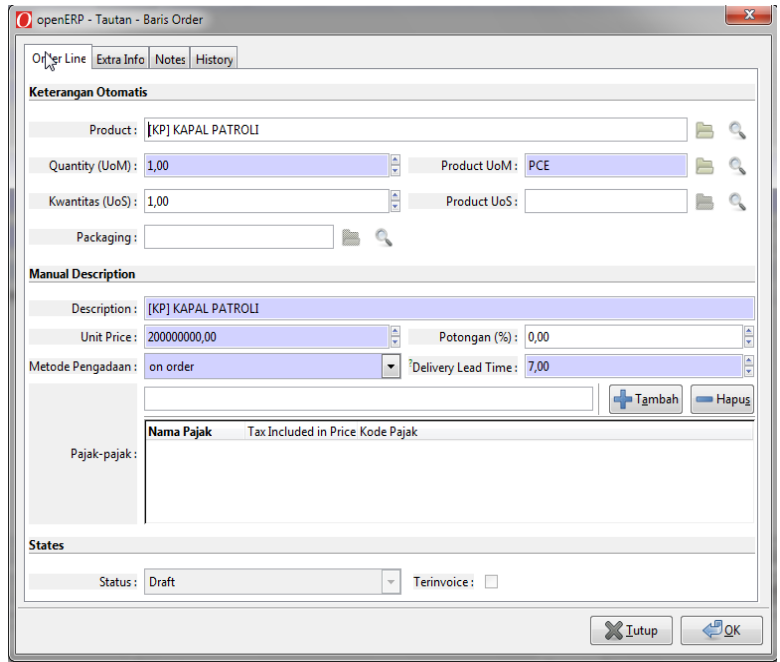

Gambar 10. Pembuatan Penawaran

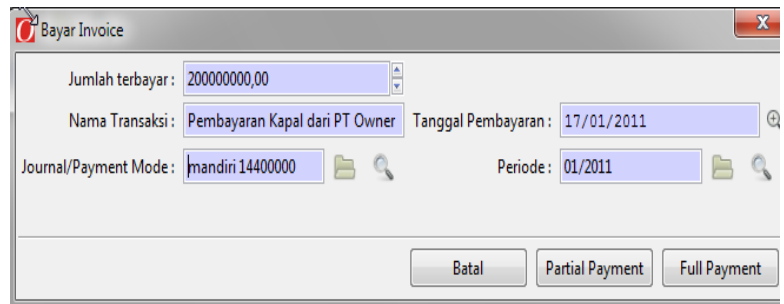

Gambar 11. Tampilan Pembayaran Konsumen 
Akibat proses pembayaran tersebut terjadi pergeseran pada laporan keuangan seperti pada Gambar 12.

\begin{tabular}{llrrr} 
Kode & Akun & Debit & Kredit & Saldo \\
\hline 0 & PT XYZ Shipyard & 762000400,00 & 7620004000,00 & 0,00 \\
\hline 1 & Balance Sheet & 581000200,00 & 562000400,00 & 18999800,00
\end{tabular}

Gambar 12. Laporan Neraca Saldo

\section{KESIMPULAN DAN SARAN}

1. Berdasarkan hasil pengujian yang telah dilakukan, sistem ERP menggunakan OpenERP dapat menjawab permasalahan yang dihadapi pada proses bisnis perusahaan galangan kapal ini.

2. Dengan menggunakan sistem ERP ini dapat memberikan keuntungan, yaitu menawarkan sistem terintegrasi di dalam perusahaan, tetapi keberhasilan sistem ERP tergantung pada strategi implementasi yang diterapkan.

3. Pengguna merasakan manfaat dari sistem ERP ini. Tetapi ada keraguan dari pengguna untuk berpindah sistem, alasan utama keraguan pengguna untuk berpindah sistem adalah:

a. Faktor kultur dan tradisi perusahaan. Perusahaan merasa bahwa kultur dan tradisi proses. bisnis yang telah mereka lakukan selama bertahun-tahun cukup melekat pada mereka, sehingga ada kesulitan untuk melakukan perubahan

b. Faktor waktu, biaya, dan kesediaan orangorang yang terlibat dalam sistem untuk merubah perilaku proses bisnis.

\section{DAFTAR PUSTAKA}

1. Hoon Nah, Fiona Fui (2002). Enterprise Resource Planning Solutions \& Management. USA: IRM Press.

2. Vollman, Thomas E. (1993). Integrated production and inventory management: revitalizing the manufacturing enterprise. Illinois. Homewood.

3. Monk, Ellen. (2006). Concept in Enterprise Resource Planning. Massachusetts. Thomson Course Technology

4. Motiwalla, Luvai. V, Jeff Thompson (2009). Enterprise Systems for Management. New Jersey, USA: Pearson Education, Inc

5. Leon, A., (2005). Enterprise Resources Planning. McGraw-Hill Publishing Company Limited, New Delhi.

6. OpenERP. (2011). United State. Retrieved March 12, 2011, from https://www.openerp.com/ 